\title{
Fluconazole-Associated Hypercalcemia in Patients with Coccidioidomycosis
}

Nam H Chan ${ }^{1}$, Janis E Blair ${ }^{3}$, Sydney A Westphal ${ }^{2}$, Leila K Tehrani ${ }^{4}$ and Maria Teresa A Seville ${ }^{3 *}$

${ }^{1}$ Division of Community Internal Medicine, Mayo Clinic Hospital, Phoenix, Arizona, USA

${ }^{2}$ Division of Endocrinology, Mayo Clinic Hospital, Phoenix, Arizona, USA

${ }^{3}$ Division of Infectious Diseases, Mayo Clinic Hospital, Phoenix, Arizona, USA

${ }^{4}$ Division of Pharmacy, Mayo Clinic Hospital, Phoenix, Arizona, USA

*Corresponding author: Maria Teresa A Seville, Division of Infectious Diseases, Mayo Clinic Hospital, Phoenix, Arizona, USA, Tel: +1 480-515-6296; E-mail: seville.teresa@mayo.edu

Rec date: Mar 28, 2016; Acc date: May 12, 2016; Pub date: May 19, 2016

Copyright: (c) 2016 Chan $\mathrm{NH}$ et al. This is an open-access article distributed under the terms of the Creative Commons Attribution License, which permits unrestricted use, distribution, and reproduction in any medium, provided the original author and source are credited

\begin{abstract}
Fluconazole, voriconazole, and itraconazole may potentiate the hypercalcemic effect of other medications, although to date, triazoles alone have not been linked to hypercalcemia. We describe a case of new-onset hypercalcemia in the setting of high-dose fluconazole that resolved after changing the antifungal regimen. We reviewed our institutional database to assess the frequency of moderate or severe hypercalcemia (serum calcium $\geq 12 \mathrm{mg} / \mathrm{dL}$ ) among patients with coccidioidomycosis treated with a triazole. We identified 2,133 patients, seen from January 1, 2005, through December 20, 2012, with a diagnosis of coccidioidomycosis. Twenty-three patients (1\%) had subsequent hypercalcemia; of these, 20 patients $(87 \%)$ had moderate or severe hypercalcemia. Nine of the 20 patients $(45 \%)$ with moderate or severe hypercalcemia were taking triazoles, and most had comorbid conditions that were risk factors for hypercalcemia (tertiary hyperparathyroidism, $n=4$; multiple myeloma, $n=2$; adrenal insufficiency, $n=1$ ). The effect of fluconazole on calcium metabolism possibly is small or not clinically significant until the dose is high. Fluconazole may also contribute to hypercalcemia in patients with underlying hyperparathyroidism because of the loss of calcium's inhibitory effect on parathyroid hormone secretion. In summary, moderate or severe hypercalcemia is uncommon in coccidioidomycosis and rare in those treated with triazoles. High-dose fluconazole may be associated with symptomatic hypercalcemia, especially in patients with predisposing comorbid conditions.
\end{abstract}

Keywords: Adverse reactions; Drug-related side effects; Triazole

\section{Abbreviations}

CYP: Cytochrome P450; PTH: Parathyroid Hormone

\section{Introduction}

Triazoles are a class of commonly used antifungal agents that includes fluconazole, itraconazole, voriconazole, and posaconazole. Its mechanism of action is inhibition of fungal cytochrome P450 (CYP)dependent demethylation of lanosterol to ergosterol, which interferes with cytoplasmic membrane synthesis. Triazoles can function as both a substrate for and inhibitor of CYP enzymes, resulting in a wide range of drug-drug interactions with varying properties that are defined by the individual drugs involved $[1,2]$. Voriconazole and itraconazole are thought to potentiate the adverse effects of all-trans retinoic acid, specifically hypercalcemia, by inhibiting CYP, thereby increasing serum concentration of all-trans retinoic acid [3,4]. Fluconazole, a first-generation triazole, is generally well tolerated, with few clinically significant toxicities. It is commonly used in prophylaxis or treatment of various fungal infections, including candidiasis, cryptococcosis, and coccidioidomycosis $[1,5]$.

In the non-English language literature, 1 report describes a patient with hypercalcemia associated with the use of fluconazole and all-trans retinoic acid and another describes a patient with hypercalcemia associated with fluconazole and rifampin [6,7]. Similar cases have not been reported in the English-language literature to date. Here, we describe a patient with new-onset hypercalcemia in the setting of highdose fluconazole. We searched our institution's records to identify additional patients with moderate or severe hypercalcemia while taking triazoles for treatment or suppression of coccidioidomycosis [8-10].

\section{Case Report}

The index case patient 9 in Tables 1 and 2 was a 28 -year-old white man who was initially diagnosed with coccidioidal meningitis 6 years prior, while living in Arizona. He was treated with fluconazole $(800 \mathrm{mg}$ daily) and clinically improved. He continued the same fluconazole dose for 3 years. Subsequently, out of concern for the development of hepatotoxicity, his dose was gradually decreased over the next year to a nonstandard dose of $200 \mathrm{mg}$ daily. Ataxia developed, and coccidioidomycosis exacerbation was diagnosed. The fluconazole dose was subsequently increased back to $800 \mathrm{mg}$ daily and in the following year was decreased to $400 \mathrm{mg}$ daily; while on the $400 \mathrm{mg}$ dosage, hydrocephalus developed and the patient required ventriculoperitoneal shunting. Fluconazole dosage was subsequently increased back to 800 mg daily. Seven months later, abscesses of the brain stem and spinal column, reportedly due to coccidioidomycosis, developed and the patient required a surgical intervention. He was initially treated with amphotericin and then maintained on fluconazole 1,200 $\mathrm{mg}$ daily.

During the next 6 months, while continuing fluconazole at $1,200 \mathrm{mg}$ daily, he underwent rehabilitation and began experiencing intermittent 
Citation: Chan NH, Blair JE, Westphal SA, Tehrani LK, Seville MTA (2016) Fluconazole-Associated Hypercalcemia in Patients with

Page 2 of 5

hypercalcemia requiring fluid resuscitation. He presented to the emergency department of our institution with symptomatic hypercalcemia $(14.8 \mathrm{mg} / \mathrm{dL})$. He was treated with intravenous fluid and furosemide, and hypercalcemia resolved by day 3 . His parathyroid hormone (PTH), 1,25-dihydroxyvitamin $\mathrm{D}$, and 25-hydroxyvitamin D levels were suppressed, and PTH-related protein was negative (Table 1). A serum Coccidioides enzyme immunoassay and an immunodiffusion assay were positive for immunoglobulin $G$ and negative for immunoglobulin $M$, and complement fixation was negative. His fluconazole was discontinued on day 2 , and voriconazole $200 \mathrm{mg}$ twice daily was initiated. He was discharged on day 3. On follow-up, the voriconazole level was shown to be subtherapeutic; the dose was increased to $400 \mathrm{mg}$, twice daily, to achieve a level within the therapeutic range $(2.4 \mathrm{mcg} / \mathrm{mL})$. Two months after initiating voriconazole treatment, he had no recurrence of hypercalcemia. He was subsequently lost to follow-up.

\begin{tabular}{|c|c|c|c|c|c|c|c|c|c|}
\hline Patient & $\begin{array}{l}\text { Sex/ } \\
\text { Age,y/Race }\end{array}$ & $\begin{array}{l}\text { Sites of } \\
\text { Coccidioido- } \\
\text { mycosis and } \\
\text { Complicatio } \\
\text { ns }\end{array}$ & $\begin{array}{l}\text { Complement } \\
\text { Fixation } \\
\text { Titera }\end{array}$ & $\begin{array}{ll}\text { Time } & \text { From } \\
\text { Coccidioidomycosi } \\
\text { s Diagnosis to } \\
\text { Development } & \text { of } \\
\text { Hypercalcemia } & \end{array}$ & $\begin{array}{l}\text { Comorbid } \\
\text { Conditions } \\
\text { Contributing to } \\
\text { Hypercalcemia }\end{array}$ & $\begin{array}{l}\text { Peak } \\
\text { Calcium } \\
\text { Level, } \\
\text { mg/dL }\end{array}$ & $\begin{array}{l}\text { PTH, } \\
\mathrm{pg} / \mathrm{mLa}\end{array}$ & $\underset{\mathrm{ng} / \mathrm{mLa}, \mathrm{b}}{\operatorname{Vitamin}} \mathrm{D}$ & $\begin{array}{l}\text { PTH-Related } \\
\text { Protein, } \\
\text { pmol/mLa }\end{array}$ \\
\hline 1 & M/45/white & Pulmonary & Not available & $5 y$ & $\begin{array}{l}\text { Tertiary } \\
\text { hyperparathyroidismc }\end{array}$ & 12.1 & $131.0(\mathrm{H})$ & Not available & Not available \\
\hline 2 & F/68/white & $\begin{array}{l}\text { Pulmonary } \\
\text { with abscess }\end{array}$ & $\begin{array}{l}\text { Nonspecific } \\
\text { resultsd }\end{array}$ & $2 y$ & Multiple myeloma & 14.9 & $\begin{array}{l}\text { Not } \\
\text { available }\end{array}$ & Not available & Not available \\
\hline 3 & $\begin{array}{l}\text { F/35/Asian } \\
\text { and white }\end{array}$ & $\begin{array}{l}\text { Pulmonary } \\
\text { with } \\
\text { respiratory } \\
\text { failure, } \\
\text { meningitis }\end{array}$ & Negative & $5 y$ & $\begin{array}{l}\text { Tertiary } \\
\text { hyperparathyroidismc }\end{array}$ & 12.6 & $25.0 \mathrm{e}$ & $21(L)$ & Not available \\
\hline 4 & M/50/white & Pulmonary & Not available & $5 y$ & $\begin{array}{l}\text { Tertiary } \\
\text { hyperparathyroidism, } \\
\text { c septic shock }\end{array}$ & 12.8 & $210.8(H)$ & $15(\mathrm{~L})$ & Not available \\
\hline 5 & F/36/white & $\begin{array}{l}\text { Pulmonary } \\
\text { with } \\
\text { empyema }\end{array}$ & Negative & $5 y$ & $\begin{array}{l}\text { Tertiary } \\
\text { hyperparathyroidismc }\end{array}$ & 12.1 & $72.5(\mathrm{H})$ & $13(\mathrm{~L})$ & Not available \\
\hline 6 & M/59/white & Pulmonary & Not available & $3 y$ & None & 12.0 & $\begin{array}{l}\text { Not } \\
\text { available }\end{array}$ & Not available & Not available \\
\hline 7 & M/69/black & Pulmonary & $1: 2$ & $5 \mathrm{mo}$ & Multiple myeloma & 12.8 & $\begin{array}{l}\text { Not } \\
\text { available }\end{array}$ & Not available & Not available \\
\hline 8 & M/68/black & Pulmonary & $1: 256$ & $5 \mathrm{mo}$ & Adrenal insufficiency & 17.2 & $<6.0(\mathrm{~L})$ & $16(\mathrm{~L})$ & 0.7 \\
\hline $\begin{array}{l}9 \text { (index } \\
\text { patient) }\end{array}$ & M/28/white & $\begin{array}{l}\text { Central } \\
\text { nervous } \\
\text { system with } \\
\text { spinal column } \\
\text { abscess and } \\
\text { brain } \\
\text { abscess }\end{array}$ & Negative & $6 y$ & None & 14.8 & $7.6(\mathrm{~L})$ & $23(L) f$ & 1.3 \\
\hline
\end{tabular}

Abbreviations: F: female; H: high; L: low; M: male; PTH: Parathyroid Hormone. aWith in 30 days of hypercalcemia. b 25-Hydroxyvitamin D. cAttributable to end-stage renal disease after kidney transplantation. dAnticomplementary activity of the specimen produced nonspecific results. elnappropriately high in the setting of hypercalcemia. f1,25-Dihydroxyvitamin $\mathrm{D}<8 \mathrm{pg} / \mathrm{mL}$

Table 1: Patient characteristics.

\section{Methods}

We searched the electronic patient records at Mayo Clinic (Phoenix Arizona) from January 1, 2005, through December 20, 2012, to identify any cases similar to the index case. A list of patients with coccidioidomycosis was generated by using International Classification of Diseases, 9th Revision, codes 114, 114.0, 114.1, 114.2, 114.3, 114.4, 114.5, and 114.9. Serum calcium values were obtained. We included only patients with a diagnosis of coccidioidomycosis that preceded development of hypercalcemia (normal serum calcium range, 8.9-10.1 $\mathrm{mg} / \mathrm{dL}$ ). This list was then narrowed to include only patients with moderate or severe hypercalcemia $(\geq 12 \mathrm{mg} / \mathrm{dL})$ because mild hypercalcemia $(10.2-11.9 \mathrm{mg} / \mathrm{dL})$ is often asymptomatic $[9,10]$. Next, we searched the medication lists of these patients to identify those who were taking triazoles, including fluconazole, itraconazole, voriconazole, and posaconazole, within 30 days before the onset of moderate or severe hypercalcemia. Finally, we reviewed records on this filtered list of patients with coccidioidomycosis who had development of moderate or severe hypercalcemia while taking triazoles (Figure1). 
Citation: Chan NH, Blair JE, Westphal SA, Tehrani LK, Seville MTA (2016) Fluconazole-Associated Hypercalcemia in Patients with

Page 3 of 5

\begin{tabular}{|c|c|c|c|c|c|c|}
\hline Patient & Purpose of Triazole & Triazole Used & $\begin{array}{l}\text { Daily } \\
\text { Dose, mg }\end{array}$ & $\mathrm{mL} / \mathrm{min} / 1.73 \mathrm{~m} 2$ & Interventions & Outcome \\
\hline \multirow[t]{2}{*}{1} & \multirow[t]{2}{*}{$\begin{array}{l}\text { Long-term suppression for post- } \\
\text { transplant immuno-suppression }\end{array}$} & \multirow[t]{2}{*}{ Fluconazole } & \multirow[t]{2}{*}{100} & \multirow[t]{2}{*}{$\geq 60$} & \multirow[t]{2}{*}{ Decreased Calcium intake } & $\begin{array}{l}\text { Resolved in } 4 \mathrm{~d} \text {, no change in } \\
\text { fluconazole }\end{array}$ \\
\hline & & & & & & PTH normalized in $3 \mathrm{mo}$ \\
\hline 2 & $\begin{array}{l}\text { Long-term suppression while on } \\
\text { chemotherapy }\end{array}$ & Voriconazolea & 200 & 30 & $\begin{array}{ll}\text { Discontinued } & \\
\text { lenalidomideb } & \text { (clinical } \\
\text { trial), initiated } & \text { salvage } \\
\text { chemotherapy } & \end{array}$ & $\begin{array}{l}\text { Resolved in } 13 \mathrm{~d} \text {, no change in } \\
\text { voriconazole }\end{array}$ \\
\hline \multirow[t]{2}{*}{3} & \multirow[t]{2}{*}{$\begin{array}{l}\text { Long-term suppression for } \\
\text { secondary prophylaxis }\end{array}$} & \multirow[t]{2}{*}{ Fluconazole } & \multirow[t]{2}{*}{800} & \multirow[t]{2}{*}{47} & \multirow[t]{2}{*}{ Fluid, parathyroidectomy } & $\begin{array}{l}\text { After } 3 \mathrm{~d} \text {, fluconazole reduced to } \\
400 \mathrm{mg} / \mathrm{d} \text {, with calcium ranging } \\
\text { from } 10.4-12.6 \mathrm{mg} / \mathrm{dL}\end{array}$ \\
\hline & & & & & & $\begin{array}{l}\text { Without further change to } \\
\text { fluconazole, hypercalcemia } \\
\text { resolved in } 5 \text { mo after } \\
\text { parathyroidectomy }\end{array}$ \\
\hline \multirow[t]{2}{*}{4} & \multirow[t]{2}{*}{$\begin{array}{l}\text { Long-term suppression for post- } \\
\text { transplant immuno-suppression }\end{array}$} & \multirow[t]{2}{*}{ Fluconazole } & \multirow[t]{2}{*}{200} & \multirow[t]{2}{*}{$\geq 60$} & \multirow[t]{2}{*}{$\begin{array}{l}\text { Fluid, } \\
\text { cinacalcet }\end{array}$ increased } & $\begin{array}{l}\text { Resolved after } 2 \text { mo after } \\
\text { increasing cinacalcet (except for } 2 \\
\text { recurrences during septic shock) }\end{array}$ \\
\hline & & & & & & $\begin{array}{l}\text { After } 9 \mathrm{mo} \text {, fluconazole was } \\
\text { discontinued after transplant } \\
\text { kidney nephrectomy and } \\
\text { cessation of immunosuppressants }\end{array}$ \\
\hline 5 & $\begin{array}{l}\text { Long-term suppression for } \\
\text { secondary prophylaxis }\end{array}$ & Fluconazole & 200 & 58 & Cinacalcet & $\begin{array}{l}\text { Resolved in } 11 \mathrm{~d} \text {, no change in } \\
\text { fluconazole }\end{array}$ \\
\hline \multirow[t]{2}{*}{6} & \multirow{2}{*}{$\begin{array}{l}\text { Long-term suppression while on } \\
\text { immuno-suppressantsc }\end{array}$} & \multirow[t]{2}{*}{ Fluconazole } & \multirow[t]{2}{*}{200} & \multirow[t]{2}{*}{$\geq 60$} & \multirow[t]{2}{*}{ Fluid } & Resolved in $1 \mathrm{~d}$ \\
\hline & & & & & & $\begin{array}{l}\text { Fluconazole was discontinued } \\
\text { within } 30 \mathrm{~d} \text { of the episode of } \\
\text { hypercalcemia after cessation of } \\
\text { immunosuppressants }\end{array}$ \\
\hline 7 & Treatment & Fluconazole & 400 & 52 & $\begin{array}{l}\text { Fluid, } \\
\text { pamidronate }\end{array}$ & $\begin{array}{l}\text { Resolved in } 4 \mathrm{~d} \text {, no change in } \\
\text { fluconazole }\end{array}$ \\
\hline 8 & Treatment & Fluconazole & 800 & 36 & $\begin{array}{l}\text { Fluid, pamidronate, } \\
\text { hydrocortisone, } \\
\text { discontinued fluconazole, } \\
\text { liposomal amphotericin for } \\
5 \text { d then changed to } \\
\text { voriconazole (200 mg, } \\
\text { twice daily) }\end{array}$ & $\begin{array}{l}\text { Resolved in } 5 \mathrm{~d} \text {, no recurrence } \\
\text { while taking voriconazole }\end{array}$ \\
\hline 9 & Treatment & Fluconazole & 1,200 & 56 & 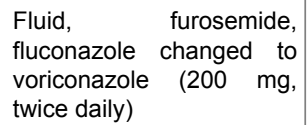 & $\begin{array}{l}\text { Resolved in } 3 \mathrm{~d} \text {, no recurrence } \\
\text { while taking voriconazole }\end{array}$ \\
\hline
\end{tabular}

Table 2: Interventions and outcomes.

\section{Results}

We identified 2,133 patients with a diagnosis of coccidioidomycosis. The diagnosis preceded development of hypercalcemia for 23 patients. Twenty (87\%) had moderate or severe hypercalcemia; of these, 9 (45\%) had been taking triazoles before hypercalcemia developed. Specifically, 8 patients were taking fluconazole and 1 was taking voriconazole. Six patients were men. Seven patients had comorbid conditions that were risk factors for hypercalcemia (Table 1). Patient 8 was the only case with a high Coccidioides titer (1:256); the remaining patients had negative or low titer or no clinical evidence of dissemination.

Table 2 shows interventions and outcomes for each patient. Concurrent with hypercalcemia management, the antifungal regimen was changed from fluconazole to voriconazole for patients 8 and 9 , with no recurrence of hypercalcemia at last follow-up (19 and 2 months, respectively). Both were taking high-dose fluconazole (800 and $1,200 \mathrm{mg}$ daily, respectively) before the development of hypercalcemia. Hypercalcemia did not improve rapidly for patient 3, 
even after reducing the fluconazole dose by half. Patient 4 discontinued fluconazole after transplant kidney nephrectomy and cessation of immunosuppressive medications. Patient 6 discontinued fluconazole within 30 days of the hypercalcemia episode. Hypercalcemia resolved in the patients 1, 5, and 7 without any changes to fluconazole. Patient 2 was taking voriconazole when hypercalcemia developed. She had multiple myeloma and changes were made to her chemotherapy regimen. Hypercalcemia resolved without any changes to voriconazole.

\section{Discussion}

Coccidioidomycosis is rarely linked with hypercalcemia, despite its association with a granulomatous immune response [11-16]. In our large cohort of patients with coccidioidomycosis, approximately $1 \%$ of patients had subsequent hypercalcemia. In the English-language literature, 22 cases of hypercalcemia attributed to coccidioidomycosis have been reported. All were complicated by dissemination, with calcium levels as high as $15.6 \mathrm{mg} / \mathrm{dL}$ [11-16]. In our 9 patients, 6 had complement fixation titers available, and only patient 8 had a high titer (1:256) with no clinical evidence of dissemination. Patients 3 and 9, the cases with central nervous system involvement, were receiving longterm fluconazole therapy with negative titer and no clinical evidence of relapse. In patients 2, 5, and 7, coccidioidomycosis did not appear to be a contributing factor to hypercalcemia.

\section{Patients with coccidioidomycosis identified from database $(n=2,133)$}

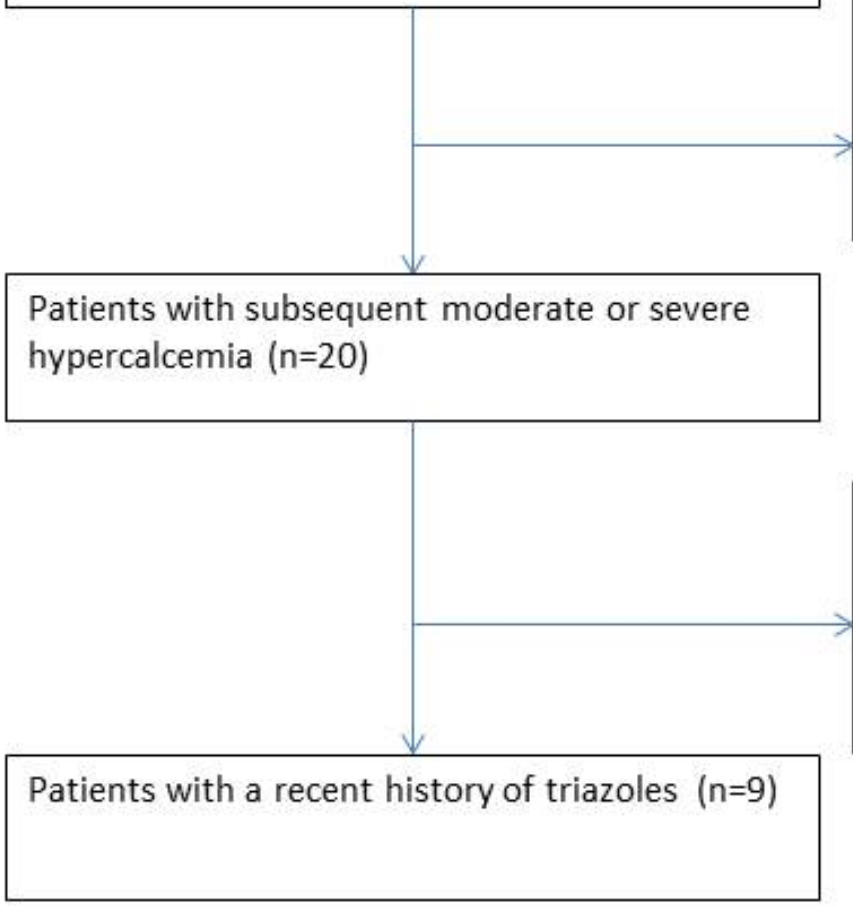

\section{Excluded:}

- Coccidioidomycosis did not precede hypercalcemia $(n=2,110)$

- Calcium $<12.0 \mathrm{mg} / \mathrm{dL}(\mathrm{n}=3)$
Excluded:

- Did not take triazoles $<30 \mathrm{~d}$ before hypercalcemia developed $(n=11)$

Figure 1: Identification of Patients with coccidioidomycosis and subsequent development of moderate or severe hypercalcemia while taking triazoles.

Because coccidioidomycosis is an uncommon cause of hypercalcemia, other causes such as medications should be considered. For the index patient, medication changes (from fluconazole to voriconazole) had a temporal relationship with resolution of hypercalcemia. His Coccidioides titer was negative at the time of hypercalcemia, he had no comorbid conditions that were thought to cause hypercalcemia, and his medications other than fluconazole were not known to cause hypercalcemia. Fluconazole, voriconazole, and itraconazole are all potent inhibitors of CYP enzymes, with CYP3A4 and CYP2C9 being inhibited mainly by voriconazole but also by fluconazole [17]. All-trans retinoic acid, the active metabolite of vitamin $\mathrm{A}$, is catabolized by CYP enzymes, including CYP3A4 and
CYP2C9 [18]. Inhibition of these enzymes by high-dose triazoles and subsequent reduction in the rate of all-trans retinoic acid catabolism has been reported to potentiate the hypercalcemic effects $[3,4]$. The effect of fluconazole on calcium metabolism might be small or it might not become clinically significant until the dose is high (eg, the 1,200 mg daily dose in our index patient). A high dose might have contributed to the most severe case of hypercalcemia in this series: patient 8 (calcium level, $17.2 \mathrm{mg} / \mathrm{dL}$ ) was taking $800 \mathrm{mg}$ of fluconazole daily in the setting of marked renal insufficiency. Indeed, dosedependent effects have been reported in fluconazole-associated drug interactions and toxicities [19-23]. 
Page 5 of 5

Another possible mechanism for the development of hypercalcemia with fluconazole treatment may be an underlying alteration in calcium homeostasis. In healthy subjects, non-parathyroid-induced increase in serum calcium inhibits PTH secretion, thereby maintaining normal serum calcium levels. However, for patients with primary and tertiary hyperparathyroidism, parathyroid function is autonomous and this compensatory mechanism is lost, leading to overt hypercalcemia [24]. Hydrochlorothiazide might exacerbate PTH-mediated hypercalcemia because of the loss of calcium's inhibitory effect on PTH secretion [24-26]. Fluconazole possibly contributed to PTH-mediated hypercalcemia in this fashion in patients $1,3,4$, and 5 , all of whom had tertiary hyperparathyroidism attributable to end-stage renal disease after kidney transplantation. When the underlying PTH-mediated hypercalcemia was addressed by cinacalcet (patients 4 and 5), parathyroidectomy (patient3), or eventual involution of hyperplastic parathyroid glands (patient 1), the calcium level normalized through restoration of calcium homeostasis, despite continuing fluconazole treatment.

Our study has several limitations. As a retrospective study, we did not have measurements of PTH and complement fixation titer on all patients, and the adjustment of triazoles, if any, was not standardized. Serum albumin levels were not available in some cases, and therefore we were unable to correct the calcium measurements. Patients may have had laboratory testing outside our facility, and results were not available for review. We excluded patients with mild hypercalcemia because it is often asymptomatic [10]. Seven of the 9 patients had comorbid conditions that are known risk factors for hypercalcemia, making it difficult to isolate the effect of triazoles on serum calcium levels. In addition, as a renal transplant center, our patient population likely has a higher prevalence of tertiary hyperparathyroidism, which can cause hypercalcemia. Finally, our study was conducted at a tertiary referral center; therefore, the results may not be broadly generalizable.

In summary, moderate or severe hypercalcemia is uncommon in coccidioidomycosis and is rare in those treated with triazoles. Highdose fluconazole may be associated with symptomatic hypercalcemia, especially in patients with predisposing comorbid conditions.

\section{References}

1. Ashley ESD, Lewis R, Lewis JS, Martin C, Andes D (2006) Pharmacology of systemic antifungal agents. Clin Infect Dis 43: S28-S39.

2. Bruggemann RJ, Alffenaar JW, Blijlevens NM, Billaud EM, Kosterink JG, et al. (2009) Clinical relevance of the pharmacokinetic interactions of azole antifungal drugs with other coadministered agents. Clin Infect Dis 48: 1441-1458.

3. Bennett MT, Sirrs S, Yeung JK, Smith CA (2005) Hypercalcemia due to all trans retinoic acid in the treatment of acute promyelocytic leukemia potentiated by voriconazole. Leuk Lymphoma 46: 1829-1831.

4. Cordoba R, Ramirez E, Lei SH, Lopez de la Guia A, et al. (2008) Hypercalcemia due to an interaction of all-trans retinoic acid (ATRA) and itraconazole therapy for acute promyelocytic leukemia successfully treated with zoledronic acid. Eur J Clin Pharmacol. 64: 1031-1032.

5. Zonios DI, Bennett JE (2008) Update on azole antifungals. Semin Respir Crit Care Med 29: 198-210.

6. Bani-Sadr F, Hoff J, Chiffoleau A, Allavena C, Raffi F (1998) [Severe hypercalcemia in a patient treated with fluconazole and rifampicin]. Presse Med 27: 860.
7. Hisatake J, Shimozuma J (2008) [Hypercalcemia associated with all-trans retinoic acid therapy for microgranular type acute promyelocytic leukemia]. Rinsho Ketsueki 49: 408-412.

8. Berg SL, Cairo MS, Russell H, Ayello J, Ingle AM, et al. (2011) Safety, pharmacokinetics, and immunomodulatory effects of lenalidomide in children and adolescents with relapsed/refractory solid tumors or myelodysplastic syndrome: a Children's Oncology Group Phase I Consortium report. J Clin Oncol 29: 316-323.

9. Grey A (2012) Nonsurgical management of mild primary hyperparathyroidism - a reasonable option. Clin Endocrinol (Oxf) 77: 639-644.

10. Pellitteri PK (2010) Evaluation of hypercalcemia in relation to hyperparathyroidism. Otolaryngol Clin North Am 43: 389-397, x.

11. Caldwell JW, Arsura EL, Kilgore WB, Reddy CM, Johnson RH (2004) Hypercalcemia in patients with disseminated coccidioidomycosis. Am J Med Sci 327: 15-18.

12. Fierer J, Burton DW, Haghighi P, Deftos LJ (2012 ) Hypercalcemia in disseminated coccidioidomycosis: expression of parathyroid hormonerelated peptide is characteristic of granulomatous inflammation. Clin Infect Dis 55: e61-66.

13. Lee JC, Catanzaro A, Parthemore JG, Roach B, Deftos LJ (1977) Hypercalcemia in disseminated coccidioidomycosis. N Engl J Med 297: 431-433.

14. Parker MS, Dokoh S, Woolfenden JM, Buchsbaum HW (1984) Hypercalcemia in coccidioidomycosis. Am J Med 76: 341-344.

15. Walter RM Jr, Lawrence RM (1981) Total ionized serum calcium and parathyroid hormone levels in patients with disseminated coccidioidomycosis. Am J Med Sci 281: 97-99.

16. Westphal SA (1998) Disseminated coccidioidomycosis associated with hypercalcemia. Mayo Clin Proc 73: 893-894.

17. Niwa T, Shiraga T, Takagi A (2005) Effect of antifungal drugs on cytochrome P450 (CYP) 2C9, CYP2C19, and CYP3A4 activities in human liver microsomes. Biol Pharm Bull 28: 1805-1808.

18. Marill J, Cresteil T, Lanotte M, Chabot GG (2000) Identification of human cytochrome P450s involved in the formation of all-trans-retinoic acid principal metabolites. Mol Pharmacol 58: 1341-1348.

19. Magrath GN, Pulido JS, Montero J, Mason C, Wilson J (2010) Cystoid macular edema secondary to fluconazole toxicity. Ocul Immunol Inflamm 18: 472-474.

20. Bronstein JA, Gros P, Hernandez E, Larroque P, Molinié C (1997) Fatal acute hepatic necrosis due to dose-dependent fluconazole hepatotoxicity. Clin Infect Dis 25: 1266-1267.

21. Varhe A, Olkkola KT, Neuvonen PJ (1996) Effect of fluconazole dose on the extent of fluconazole-triazolam interaction. Br J Clin Pharmacol 42: 465-470.

22. López-Gil JA (1993) Fluconazole-cyclosporine interaction: a dosedependent effect? Ann Pharmacother 27: 427-430.

23. Wells C, Lever AM (1992) Dose-dependent fluconazole hepatotoxicity proven on biopsy and rechallenge. J Infect 24: 111-112.

24. Klimiuk PS, Davies M, Adams PH (1981) Primary hyperparathyroidism and thiazide diuretics. Postgrad Med J 57: 80-83.

25. Desai HV, Gandhi K, Sharma M, Jennine M, Singh P, et al. (2010) Thiazide-induced severe hypercalcemia: a case report and review of literature. Am J Ther 17: e234-236.

26. Strong P, Jewell S, Rinker J, Hoch D, Crapo L (1991) Thiazide therapy and severe hypercalcemia in a patient with hyperparathyroidism. West J Med 154: 338-340. 